\title{
Rapid detection of Escherichia coli in beverages using genetically engineered bacteriophage T7
}

\author{
Nicharee Wisuthiphaet ${ }^{1}$, Xu Yang ${ }^{1}$, Glenn M. Young ${ }^{1}$ and Nitin Nitin ${ }^{1} 2^{*}$
}

\begin{abstract}
Foodborne illness due to bacterial contamination is a significant issue impacting public health that demands new technology which is practical to implement by food industry. Detection of bacteria in food products and production facilities is a crucial strategy supporting food safety assessments. Bacteriophages were investigated as a tool for bacterial detection due to their ability to infect specific strain of host bacteria in order to improve sensitivity, specificity, and rapidity of bacterial detection. The results of this investigation reveal a novel method for rapid detection. The method employs a genetically engineered bacteriophage, phage T7-ALP, which expresses alkaline phosphatase. Upon infection of Escherichia coli, overexpression of alkaline phosphatase provides an opportunity for rapid sensitive detection of a signal indicative of bacterial presence in model beverage samples as low as 100 bacteria per gram. The method employs a fluorescent precipitated substrate, ELF-97, as a substrate for alkaline phosphatase activity coupled with fluorescence imaging and image analysis allowing single-cell imaging results in high detection sensitivity. The method is easily completed within less than $6 \mathrm{~h}$ enabling it to be deployed within most large industrial food processing facilities that have routine 8-h operational shifts.
\end{abstract}

Keywords: Engineered bacteriophage, Escherichia coli BL21, Alkaline phosphatase, ELF-97, Fluorescent microscope, Image analysis

\section{Introduction}

Over the past decades, foodborne disease outbreaks affect millions of people worldwide by causing burdens on public health and significant hindrance in socioeconomic development (WHO 2015). Each year, in the United States, approximately 9.4 million cases of foodborne illness were reported causing over $\$ 15.5$ billion economic burdens (Scallan et al. 2011; Hoffmann et al. 2015), including $64 \%$ of the foodborne-related deaths were caused by infection of bacteria (Scallan et al. 2011). Given that it is well-documented the leading causes of foodborne illnesses are due to contamination by bacterial pathogens, detection of these microbes in food is a critical step that ensures the safety of food and beverages

\footnotetext{
*Correspondence: nnitin@ucdavis.edu

${ }^{1}$ Department of Food Science and Technology, University of California,

Davis, CA, USA

Full list of author information is available at the end of the article
}

products before distribution to the consumers. Among all of these pathogens, Escherichia coli is probably one of the most prevalent pathogens during the past few years which resulted in foodborne illness outbreaks. According to the Centers for Disease Control and Prevention (CDC) surveillance of foodborne outbreaks in the U.S., several food products have been reported associated with $E$. coli contamination such as romaine lettuce, ground beef, and beverages including coconut water an apple juice (Marder et al. 2017). Therefore, detection of E. coli that is applicable in variety of food matrices is highly crucial.

Culture-based detection methods remain the "gold standard" for pathogen detection in food and animal feed because they provide highly accurate results; however, the major drawback of these methods is that they require 3-5 days to complete and are relatively expensive for total material and labor costs (Koyuncu and Haggblom 2009; Kralik and Ricchi 2017). Economic costs of extended production storage to allow testing and loss of food 
quality-for short shelf life foods-further negatively impact food manufacturers. Molecular-based methods, such as those employing polymerase chain reaction (PCR) provide alternative opportunities for rapid pathogen detection of bacterial pathogens. Even though PCR offers the results with only few hours of bacteria enrichment, the critical drawback of detection methods relying on PCR is that they are incapable of differentiating between viable and dead cells which leads to falsepositive results (Chapela et al. 2015; Kralik and Ricchi 2017). Economically, PCR-based methods remain accessible only to large food manufactures that have the capacity to support the technical application of this approach and the relatively high costs. On a technical level, wide use of PCR-based methods suffer from the complexity of food matrices, many of which have been demonstrated to harbor molecules that are inhibitors of PCR, resulting in decreased sensitivity or false-negative results (Rossen et al. 1992; Schrader et al. 2012). Immunological-based methods, including variations of enzyme-linked immunosorbent assays (ELISAs), have been developed in order to provide more rapid, economical and simple approach compared to the culture-based and PCR-based methods; however, on a practical level, ELISAs suffer from an inability to distinguish live from dead bacteria, from low sensitivity due to small sample volume capacity, and from low specificity due to cross-reactivity of polyclonal antibodies (Ivnitski et al. 1999; Shen et al. 2014). The limitations of these foodborne pathogen detection methods provide incentive for continued research and development into innovative novel approaches for rapid detection that have high sensitivity and specificity to detect bacterial foodborne pathogens, and can be widely adapted for use by a diversity of large and small food manufactures.

Bacteriophages or phages have drawn the attention of many researchers in the field of pathogen detection due to their high specificity to bacterial host strain which enables them to be developed as a tool for detection of specific bacterial pathogen. Phages are also capable of self-replication and produce progeny phages within the short period of time, this allows amplification of the signal intensity resulting in lower limit of detection without the requirement for any overnight enrichment (Anany et al. 2017). One significant advantage of using phages for bacterial detection is the ability to distinguish between viable and dead cells. Since phage infection and replication only occur in living bacterial cells, bacteriophagebased detection methods inherently ensure that only viable cells are targeted (Hagens and Loessner 2007). Several strategies have been employed to develop phagebased biosensors including detection of the released cell components due to phage lysis (Griffiths 1996; Chang et al. 2002; Chen et al. 2015), detection of labeled phages after their specific attachment to bacterial hosts (Hennes et al. 1995; Yim et al. 2009), and detection of the progeny phage amplification using nucleic acid-based detection techniques (González-Gil et al. 1998; Reiman et al. 2007; Kutin et al. 2009).

Recently, genetically engineered phages have been created in order to provide special features that allow greater possibilities in developing novel bacterial biosensors. Among the most promising approaches is 'Reporter Phage', where wild-type phages are genetically modified to harbor reporter genes that can only be activated once phage-host infection occurs. Expression of reporter genes inside host cells yields a detectable signal indicative of the presence of target bacteria (Smartt et al. 2012; Singh et al. 2013). Several gene-based reporters have been widely studied and incorporated into phage genome, such as lux locus for bioluminescence (Loessner et al. 1997; Kim et al. 2017), lac $Z$ encoding $\beta$-galactosidase (Goodridge and Griffiths 2002), and $g f p$ encoding green fluorescent protein (Oda et al. 2004; Piuri et al. 2009). Alcaine et al. (2015) developed genetically engineered phage T7 (phage T7-ALP) carrying phoA that results in over-expression of alkaline phosphatase after infection of $E$. coli (Alcaine et al. 2015). Phage T7-ALP provides a promising opportunity but background noise could be an issue since alkaline phosphatase is a common enzyme found in a vast array of organisms including bacteria, fungi, plants, and animals (McComb et al. 1979; Alcaine et al. 2015). Moreover, the previous research on detection of bacteriophage-mediated alkaline phosphatase production was based on enzymatic essay using substrates that yield soluble products which distribute homogeneously in the solution resulting in a diluted signal (Alcaine et al. 2015); therefore, the signal-to-noise ratio may be reduced in the presence of food.

In order to overcome this obstacle, instead of colorimetric and chemiluminescent soluble substrates, our research focused on heterogeneous detection using an alkaline phosphatase substrate 2-(5'-chloro-2phosphoryloxyphenyl)-6-chloro-4(3H)-quinazolinone (ELF-97) that, when hydrolyzed, gives a precipitated fluorescent product that localized at the site of reaction. Deposition of the precipitated ELF-97 product allows concentration of the signal which results in higher signalto-noise ratio and increased detection sensitivity. ELF-97 is a non-fluorescent water-soluble substrate that once cleaved with alkaline phosphatase will yield the product, ELF-97 alcohol, that precipitates at the site of the reaction (Huang et al. 1993; Telford et al. 1999; Duhamel et al. 2009). This outstanding feature of ELF-97 results in signal deposition allowing detection of enzyme activity at the single cell level within few minutes after the reaction 
(González-Gil et al. 1998). ELF-97 has been applied for detecting mRNA in situ hybridization (Paragas et al. 1997), cytological labelling and imaging of mammalian cells (Paragas et al. 2002), and detection of alkaline phosphatase activity in marine planktons at the singlecell level (González-Gil et al. 1998; Nedoma et al. 2003; Peacock and Kudela 2012). To the best of our knowledge, none of the previous studies have investigated the application of ELF-97 for microbial detection approaches in food systems.

With the benefit of phage T7-ALP to induce alkaline phosphatase over-expression in E. coli and the potential of ELF-97 to endogenously detect a small amount of alkaline phosphatase enzyme, this research aims to develop a novel detection method of $E$. coli in authentic beverages samples. With fluorescence imaging and image analysis, we hypothesized that this approach will provide a method able to detect low concentrations of E. coli in a variety of different beverages matrices within less than $6 \mathrm{~h}$.

\section{Materials and methods \\ Bacteriophage and bacterial strains}

Engineered bacteriophage T7-ALP was kindly provided by Dr. Sam Nugen (Cornell University). Bacteriophage T7-ALP has been amplified by inoculation of phage $10^{5}$ $\mathrm{PFU} / \mathrm{ml}$ into $10^{8} \mathrm{CFU} / \mathrm{ml}$ of log-phase $E$. coli BL21 followed by $15 \mathrm{~min}$ of incubation at $37{ }^{\circ} \mathrm{C}$ for initial infection and $10 \mathrm{~min}$ of centrifugation at $16,100 \times g$ to harvest infected bacteria. Bacteria pellet was resuspended in $15 \mathrm{ml}$ of sterile tryptic soy broth (TSB, Sigma-Aldridge, St. Louis, MO, USA) before incubation at $37{ }^{\circ} \mathrm{C}$ with $200 \mathrm{rpm}$ constant shaking for further infection. After there was no visible turbidity, $3 \mathrm{ml}$ of chloroform was added and the mixture was kept at $4{ }^{\circ} \mathrm{C}$ overnight to lyse intact cells. To separate cell debris, the mixture was centrifuged at $16,100 \times g$ for $10 \mathrm{~min}$. The upper liquid phase which contains free phage was collected and centrifuged at $16,100 \times g$ for $10 \mathrm{~min}$. The supernatant was discarded and the phage pellet was resuspended in sterile phosphate buffer saline (Fisher Scientific, Pittsburg, CA, USA) and stored at $4{ }^{\circ} \mathrm{C}$. The titer of the phage stock was enumerated by standard plaque counting assay.

The model bacteria for this research was E. coli BL21 (ATCC BAA-1025) obtained from American type culture collection. Two strains of bacteria were used as controls: Listeria innocua (ATCC 33090) kindly provided by Dr. Linda Harris (University of California, Davis) and Pseudomonas fluorescens (ATCC 13525) from American type culture collection. All bacterial strains were stored in TSB containing $15 \%(\mathrm{vol} / \mathrm{vol})$ glycerol at $-80{ }^{\circ} \mathrm{C}$. For short-term storage, the glycerol stock of bacteria was streaked onto tryptic soy agar (Sigma-Aldridge, St. Louis,
MO, USA) plates then incubated overnight at $37^{\circ} \mathrm{C}$ for $E$. coli and at $30^{\circ} \mathrm{C}$ for Listeria innocua and Pseudomonas fluorescens. The agar plates were then stored at $4{ }^{\circ} \mathrm{C}$ for further experiment.

\section{Beverage samples preparation}

Coconut water (Vita coco, 100\% coconut water) and apple juice (Signature select, 100\% apple juice) were purchased from the local grocery store. Prior to the experiment, coconut water was filtered through a 0.22 -micron syringe filter. To support the growth of bacteria and phage infection, TSB with double concentration was added to coconut water and apple juice at the ratio of 1:1. The $\mathrm{pH}$ of apple juice-TSB mixture was adjusted to 7 using $1 \mathrm{M}$ tris before filtering through a 0.22 -micron syringe filter.

\section{Bacterial inoculation, enrichment, and phage infection}

For overnight culture preparation, a single colony of bacteria from agar plate was transferred to $10 \mathrm{ml}$ of TSB and incubated at $37{ }^{\circ} \mathrm{C}$ with constant shaking at $200 \mathrm{rpm}$ for $16 \mathrm{~h}$. For inoculum preparation, $1 \mathrm{ml}$ of the overnight culture $\left(10^{9} \mathrm{CFU} / \mathrm{ml}\right)$ was centrifuged at $16,100 \times g$ for $1 \mathrm{~min}$ then the cell pellet was washed twice by resuspending in $1 \mathrm{ml}$ of sterile phosphate buffer saline. The cell suspension was serial diluted and inoculated in $10 \mathrm{ml}$ of TSB and beverages-TSB mixture; coconut water and apple juice, to the final concentration of $10^{2}$ and $10^{3} \mathrm{CFU} / \mathrm{ml}$ and incubated at $37^{\circ} \mathrm{C}$ with constant shaking (200 rpm) for $4 \mathrm{~h}$. Bacteriophage T7-ALP was added to the mixture to the final concentration of $10^{6} \mathrm{PFU} / \mathrm{ml}$ and incubated in the same condition for 15 and $30 \mathrm{~min}$.

\section{Filtration and optical detection of alkaline phosphatase activity}

To capture the infected bacterial cells, all $10 \mathrm{ml}$ of the mixtures were filtered through 0.22 -micron white polycarbonate membrane discs with a $19 \mathrm{~mm}$ diameter (Nucleopore Polycarbonate Whatman). After filtration, the filters were stained with ELF-97 alkaline phosphatase substrate using $\operatorname{ELF}^{\mathrm{TM}} 97$ Endogenous Phosphatase Detection Kit (Molecular Probes, Eugene, OR, USA). The reaction mixture was prepared by diluting the ELF-97 phosphatase substrate 1:20 in ELF-97 developing buffer (provided in the kit) then spotted $20 \mu \mathrm{l}$ of the reaction mixture on a microscopic slide. The filters were removed from a vacuum filtration system and put to the reaction mixture on the slides then another $20 \mu \mathrm{l}$ of the reaction mixture was added on the top of the filter and spread evenly on the filter surface using sterile pipette tips. The slides with filters were incubated at room temperature in the dark for $30 \mathrm{~min}$. To stop the enzymatic reaction, the filters were removed from the slides and put on the 
cellulose filter paper saturated with $1 \%$ formaldehyde for $5 \mathrm{~min}$. All filters were counterstained with red fluorescent nucleic acid stain SYTO 60 (Molecular Probes, Eugene, OR) to stain all bacterial cells present on the filter. The ELF-97-stained filters were placed on the microscopic slides pre-spotted with $10 \mu \mathrm{l}$ of $20 \mu \mathrm{M}$ SYTO 60 . Another $10 \mu \mathrm{l}$ SYTO 60 was dropped on top of the filters and covered with cover glasses then observed under the Leica TCS SP8 STED $3 \times$ confocal microscope (Leica Microsystems, Mannheim, Germany) equipped with a white light laser for excitation. ELF-97 was excited by $405 \mathrm{~nm}$ STED laser and the fluorescent emission was collected at $452-560 \mathrm{~nm}$. SYTO 60 was excited at $647 \mathrm{~nm}$ white light laser and the fluorescent emission was collected at $654-752 \mathrm{~nm}$. All images were taken with a $100 \times$ oil-immersion objective (NA 1.4) with the laser power $5 \%$. For negative control, the experiment was performed as described earlier with E. coli BL21 without adding phage and $L$. innocua and P. fluorescens. Experiments for all conditions were performed in triplicates.

\section{Image analysis for mean fluorescence intensity}

Image analysis was performed using Image (available for download at https://imagej.nih.gov/ij/ download. html). All images were binarized to have images of cells in black and background in white. The intensity threshold for each image was set at 70 when the maximum intensity was 225 . The mean density of each cell particle was obtained using Imagej's particle analysis package. To eliminate the noise background signal, only particles with the size larger than 0.5 pixels were analyzed. The analysis of multiple images was repeated for each condition $(\mathrm{N}=15)$.

\section{Alkaline phosphatase assay using FDP soluble fluorescent substrate}

Fluorimetric detection of alkaline phosphatase was performed using Amplite ${ }^{\mathrm{TM}}$ Fluorimetric Alkaline Phosphatase Assay Kit (Green Fluorescence) (AAT Bioquest, Biomol, Hamburg, Germany). E. coli BL21 with the concentration of $10^{2}, 10^{3}$, and $10^{4} \mathrm{CFU} / \mathrm{ml}$ were inoculated in $1 \mathrm{ml}$ of beverage samples-TSB mixture before incubation at $37^{\circ} \mathrm{C}$ with constant shaking $(200 \mathrm{rpm})$ for $4 \mathrm{~h}$. For phage infection, $10^{6} \mathrm{PFU} / \mathrm{ml}$ of T7-ALP phage was inoculated then incubated at the same condition for $30 \mathrm{~min}$. The mixtures were centrifuged $(16,100 \times g)$ for $10 \mathrm{~min}$ to separate the cell debris. Fifty microliters of the samples were mixed with the FDP substrate provided from the kit in a black flat-bottom 96-well plate. The fluorescence was measured using a microplate reader TECAN SpectraFluor Plus (TECAN Austria GmbH, Grödig, Austria) with excitation at $488 \mathrm{~nm}$ and emission at $520 \mathrm{~nm}$. The experiments were performed in parallel with the blank which is $1 \mathrm{ml}$ of beverage sample without $E$. coli and phage inoculation and negative controls of $E$. coli without phage infection.

\section{Statistical analysis}

All experiments were done in triplicate independently for each condition. For image analysis, the total number of 15 images were analyzed $(\mathrm{N}=15)$. The mean and standard deviation values were calculated within the samples in all cases. The Tukey's HSD test was performed on the mean intensity of the fluorescent images and the signal/ noise ratio of the fluorometric assay of alkaline phosphatase using FDP substrate in order to define the limit of detection. All statistical analysis was done using the $\mathrm{R}$ software.

\section{Results}

Schematic diagram of bacterial detection methods based on T7-ALP phage infection

The protocols of $E$. coli detection based on the assay of phage-induced alkaline phosphatase activity using soluble and precipitated fluorescent substrates are shown in Fig. 1. Both methods started with $4 \mathrm{~h}$ of enrichment of $E$. coli. The initial concentration of $E$. coli in both beverage samples were $10^{2} \mathrm{CFU} / \mathrm{ml}$ and $10^{3} \mathrm{CFU} / \mathrm{ml}$. After $4 \mathrm{~h}$ of enrichment, engineered phage T7-ALP was added to the sample allowing phage infection and expression of alkaline phosphatase. Both methods focus on detection of phage-induced alkaline phosphatase activity. The first method involves filtration to capture bacterial cells on the filter and detection of phage-induced alkaline phosphatase using ELF-97 substrate which is cell permeable and yields bright precipitated fluorescent product that can be visualized under the fluorescent microscope. Another approach is based on using FDP alkaline phosphatase substrate to detect alkaline phosphatase activity. The soluble fluorescent product of FDP was detected by measuring fluorescent signal using a microplate reader.

\section{Optical detection of E. coli using ELF-97 fluorescent substrate in TSB}

Before investigating the detection method in authentic beverage samples, detection of E. coli in TSB was first performed. In $10 \mathrm{ml}$ of sterile TSB, $10^{2} \mathrm{CFU} / \mathrm{ml}$ and $10^{3}$ $\mathrm{CFU} / \mathrm{ml}$ were inoculated and incubated at $37^{\circ} \mathrm{C}$ for $4 \mathrm{~h}$ with constant shaking at $200 \mathrm{rpm}$. T7-ALP phage with the final concentration of $10^{6} \mathrm{PFU} / \mathrm{ml}$ was added then the mixture was incubated at the same condition for 15 and $30 \mathrm{~min}$. Ten milliliters of the mixture were filtrated onto a $0.2 \mu \mathrm{m}$ white polycarbonate filter. E. coli BL21 in the same concentrations but without phage infection served as negative controls. Detection of alkaline phosphatase activity was performed by adding ELF-97 


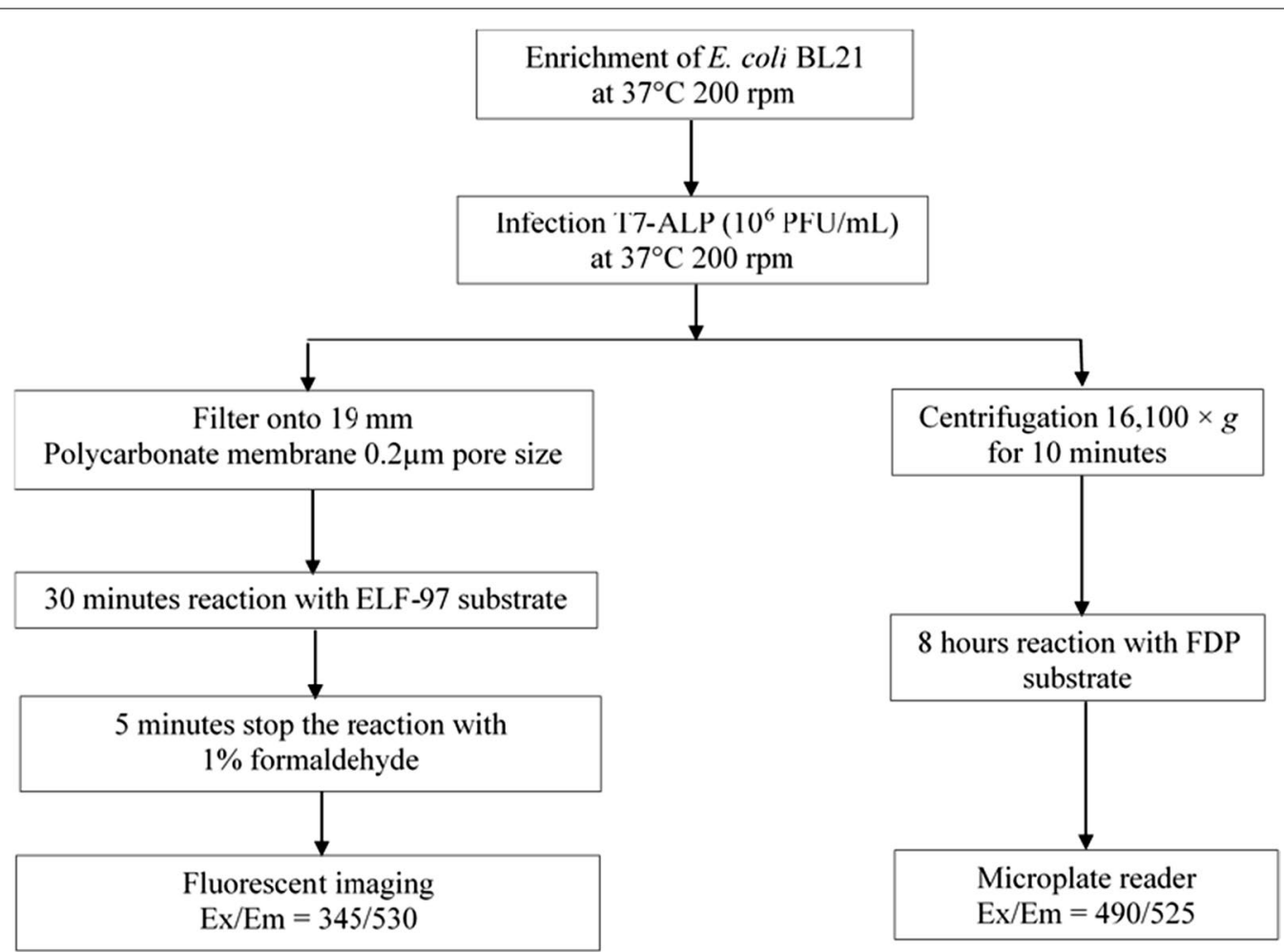

Fig. 1 Schematic diagram of detection protocol based on alkaline phosphatase activity assay using soluble alkaline phosphatase substrate (FDP) and insoluble alkaline phosphatase substrate (ELF-97)

substrate directly onto bacterial cells captured on the filter. After counterstaining with syto60, the filters were observed under a confocal fluorescent microscope.

Representative fluorescent images are illustrated in Fig. 2. The total bacterial cells present on the filter appeared in red due to SYTO-60 red fluorescent nucleic acid stain. Without phage infection, Fig. 2a, d reveal that $E$. coli has no alkaline phosphatase activity after $4 \mathrm{~h}$ of enrichment without phage infection at a concentration of $10^{2} \mathrm{CFU} / \mathrm{ml}$ and $10^{3} \mathrm{CFU} / \mathrm{ml}$, respectively. Figure $2 \mathrm{~b}, \mathrm{c}$ represent the fluorescent images of E. coli cells after 15 and $30 \mathrm{~min}$ of infection by phage T7-ALP when the initial bacterial concentration was $10^{2} \mathrm{CFU} / \mathrm{ml}$. At both time points, at least one E. coli cell cluster per image was observed to have fluorescent signal localized inside the cell showing that the cell was infected and alkaline phosphatase was produced but the cell was not yet lysed by the phage. Figure 2e, f represent images of $E$. coli cells after 15 and $30 \mathrm{~min}$ of infection by phage T7-ALP when the initial bacterial concentration was $10^{3} \mathrm{CFU} / \mathrm{ml}$. After $15 \mathrm{~min}$ of phage infection, few cells exhibit green fluorescence as shown in Fig. 2e but after the infection continue to $30 \mathrm{~min}$, a representative image shows an increase in the number of cells that exhibit green fluorescence as show in Fig. 2f.

\section{Evaluation of issue of potential false positive identification of $E$. coli}

Phage T7 infection is specific to E. coli; therefore, phage T7 will not be able to infect other bacterial strains or species thereby eliminating false positive results if deployed as a bacterial detection method. However, to more rigorously investigate this assumption, the specificity of this phage approach to E. coli detection was challenged using two food related bacteria: L. innocua and P. fluorescens. Both strains with an initial concentration of $10^{3} \mathrm{CFU} / \mathrm{ml}$ were enriched in TSB for $4 \mathrm{~h}$ before infection with $10^{6}$ $\mathrm{PFU} / \mathrm{ml}$ of phage T7-ALP for $30 \mathrm{~min}$. After filtration and reaction with ELF-97, there was no significant green fluorescent signal was detected (Fig. 3).

\section{Optical detection of $E$. coli in realistic challenging beverage matrices}

This detection method was also studied for detection of E. coli in an authentic complex beverage matrix. First, coconut water was examined, which predominantly contains sugar and minerals (Prades et al. 2012). The 


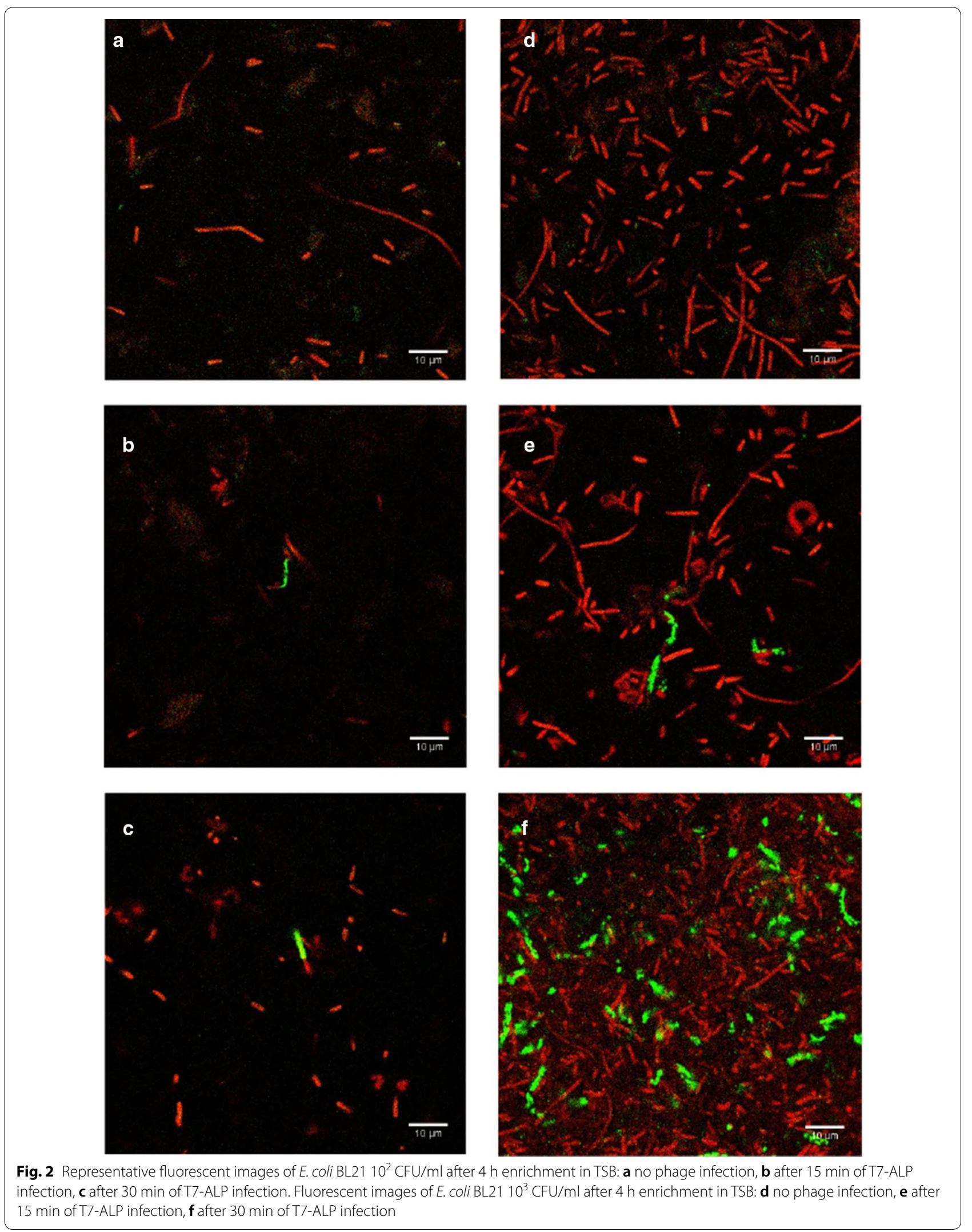




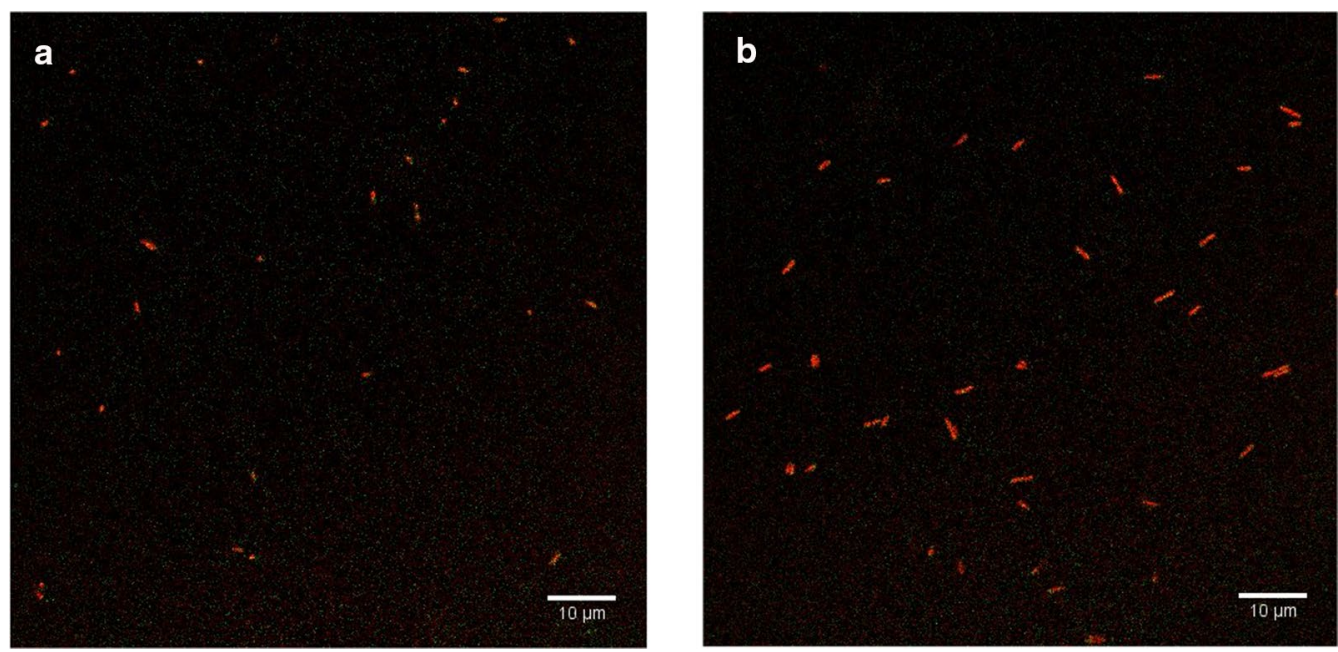

Fig. 3 L innocua (a), P. fluorescens (b) after $4 \mathrm{~h}$ enrichment in TSB and 30-min infection with bacteriophage T7-ALP

coconut water was filtered through $0.22 \mu \mathrm{m}$ syringe filter to ensure no contamination of other bacteria then mixed with double-concentrated TSB to support bacterial growth of inoculated bacteria. E. coli with the concentration of $10^{2} \mathrm{CFU} / \mathrm{ml}$ and $10^{3} \mathrm{CFU} / \mathrm{ml}$ was inoculated into the coconut water-TSB mixture and incubated at $37{ }^{\circ} \mathrm{C}$ with $200 \mathrm{rpm}$ constant shaking for $4 \mathrm{~h}$ for enrichment. For phage infection, $10^{6} \mathrm{PFU} / \mathrm{ml}$ was added and co-incubated at the same condition for 15 and $30 \mathrm{~min}$. The mixtures were filtered through $0.2 \mu \mathrm{m}$ white polycarbonate membrane before adding ELF-97 substrate and looked under the microscope. Representative fluorescent images were shown in Fig. 4. Figure 4a, d show the fluorescent images of $10^{2} \mathrm{CFU} / \mathrm{ml}$ and $10^{3} \mathrm{CFU} / \mathrm{ml}$ of $E$. coli, respectively. After $4 \mathrm{~h}$ of enrichment with no phage infection, the images show total cells with red fluorescence without visible green fluorescence of cell or background noise indicating that coconut water-TSB does not induce alkaline phosphatase production by $E$. coli.

Figure $4 \mathrm{~b}$ illustrates fluorescent image of bacteria $10^{2}$ CFU/ml of E. coli after $4 \mathrm{~h}$ of enrichment and $15 \mathrm{~min}$ of phage T7-ALP infection. There was at least one cluster of cells per image that has green fluorescence of ELF-97 product. Even though the infection time was extended to $30 \mathrm{~min}$, the number of cells with alkaline phosphatase activity did not increase. This result is similar to the result observed for phage T7-ALP infection of E. coli grown in TSB (Fig. 2).

In the case of $E$. coli $10^{3} \mathrm{CFU} / \mathrm{ml}$, phage T7-ALP infection occurred a significant green fluorescent signal was detected. Interestingly, the signal occurred as within multiple small particles scattered outside the cells as can be seen in Fig. 4e. After the infection continued to $30 \mathrm{~min}$, there was an increase in number of small punctate green fluorescence particles (Fig. 4f).

As an alternative beverage sample, apple juice was tested for $E$. coli using this methodology. Apple juice predominantly has sugars and minerals but has an acidic $\mathrm{pH}$ less than 6. E. coli contaminated apple juice was used to set up an enrichment. An apple juice-TSB mixture was adjusted to $\mathrm{pH} 7$ before filtration through 0.22 -micron syringe filter and bacterial inoculation. The detection method using engineered phage T7-ALP and alkaline phosphatase substrate ELF-97 was performed as described earlier. Representative fluorescent images of $E$. coli in apple juice-TSB after reaction with ELF-97 are shown in Fig. 5. Figure 5a, d show the results of $E$. coli after $4 \mathrm{~h}$ of enrichment without phage infection with initial concentration of $\mathrm{E}$. coli of $10^{2} \mathrm{CFU} / \mathrm{ml}$ and $10^{3}$ $\mathrm{CFU} / \mathrm{ml}$, respectively. After $4 \mathrm{~h}$ of enrichment, the bacteria appeared to have filamentous morphology; however, there was no cell with visible green fluorescent signal from precipitated ELF-97 fluorescent product.

Following $15 \mathrm{~min}$ of phage T7-ALP infection, images of bacteria originating from a concentration of $10^{2}$ and $10^{3}$ $\mathrm{CFU} / \mathrm{ml}$ were observed as shown in Fig. 5b, e, respectively. This revealed green fluorescent signal marking the location of significant alkaline phosphatase activity and the signals were very bright and easy to distinguished from the background. When the infection was extended to $30 \mathrm{~min}$ prior to imaging, there was more than one cell with green fluorescence and the signal became more intense and appeared along the filamentous arrangement, Fig. 5c, f. For Apple juice, signal was always confined to 

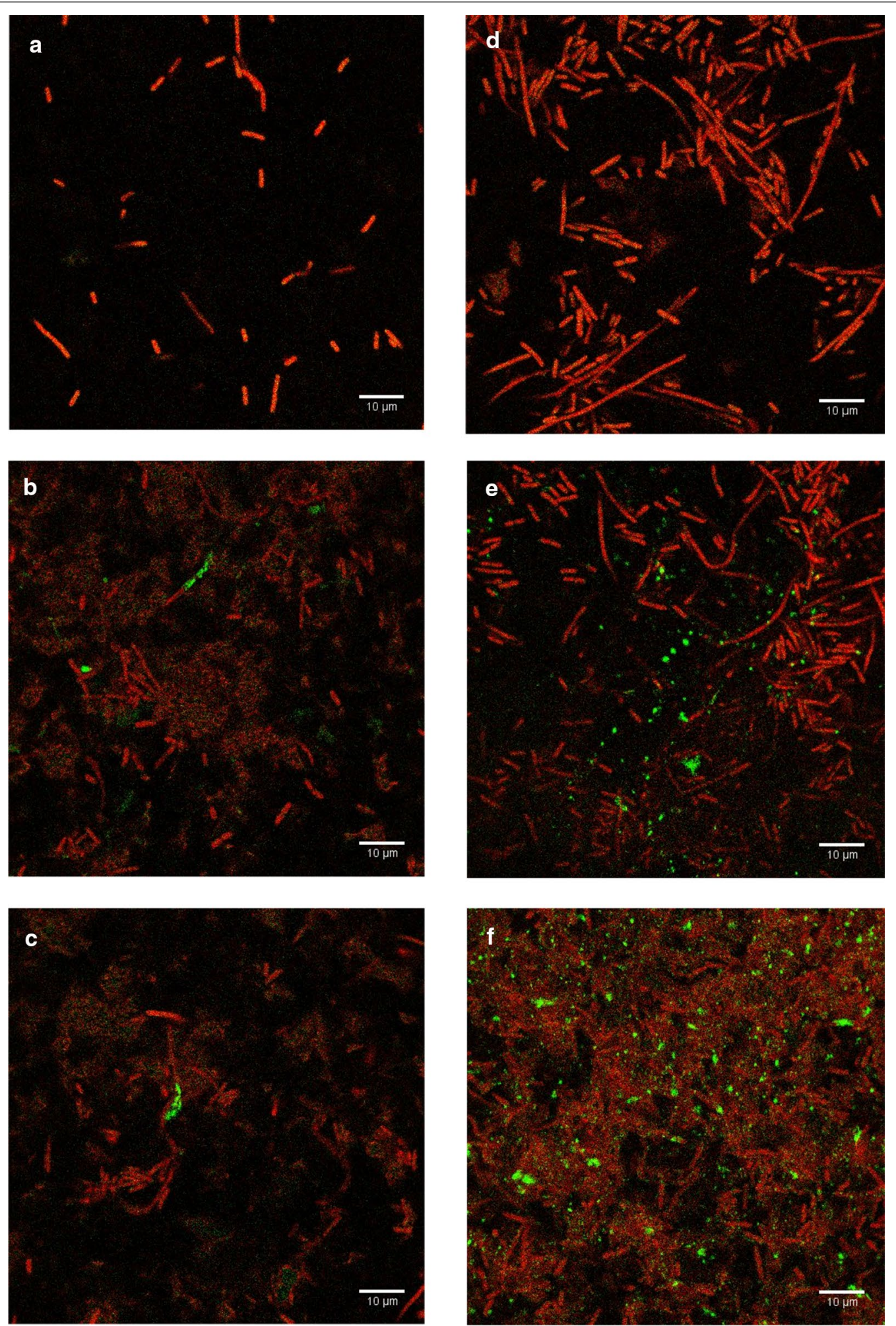

Fig. 4 Representative fluorescent images of $E$. coli BL21 $10^{2} \mathrm{CFU} / \mathrm{ml}$ after $4 \mathrm{~h}$ enrichment in coconut water-TSB mixture: a no phage infection, b after 15 min of T7-ALP infection, c after 30 min of T7-ALP infection. Fluorescent images of E. coli BL21 $10^{3} \mathrm{CFU} / \mathrm{ml}$ after 4 h enrichment in coconut water-TSB mixture: $\mathbf{d}$ no phage infection, e after 15 min of T7-ALP infection, $\mathbf{f}$ after 30 min of T7-ALP infection 

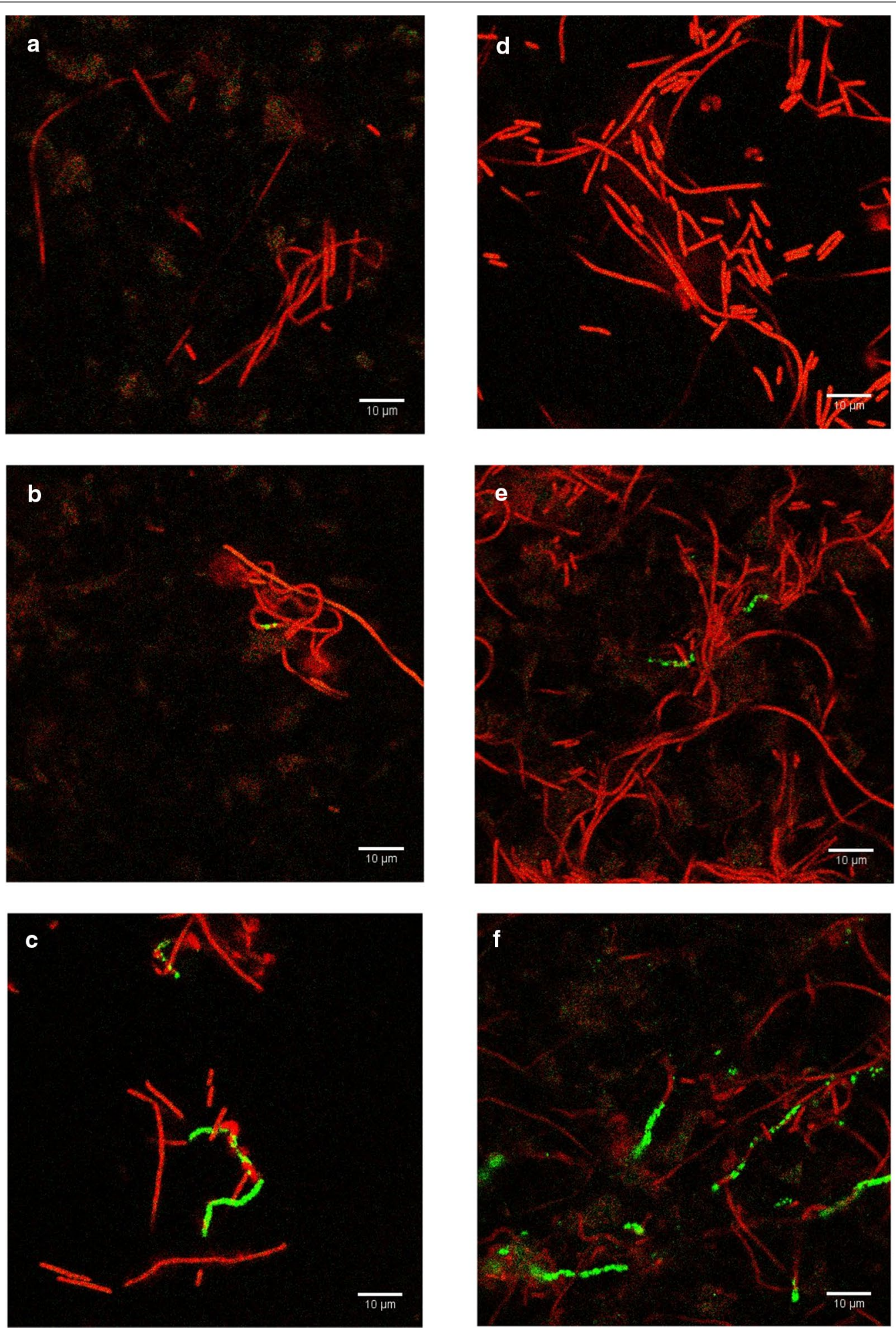

Fig. 5 Representative fluorescent images of E. coli BL21 10² CFU/ml after $4 \mathrm{~h}$ enrichment in apple juice-TSB mixture: a no phage infection, $\mathbf{b}$ after 15 min of T7-ALP infection, c after 30 min of T7-ALP infection. Fluorescent images of E. coli BL21 $10^{3} \mathrm{CFU} / \mathrm{ml}$ after 4 h enrichment in apple juice-TSB mixture: $\mathbf{d}$ no phage infection, e after $15 \mathrm{~min}$ of T7-ALP infection, $\mathbf{f}$ after $30 \mathrm{~min}$ of T7-ALP infection 
cells, with no apparent small green fluorescent particle, suggesting that in this experiment situation there was no loss of bacterial cell integrity.

Image analysis of T7-ALP infected $E$. coli fluorescent images Figure $6 \mathrm{a}-\mathrm{c}$ show the level of mean intensity of the fluorescent signal of ELF-97 precipitated fluorescent product in TSB, coconut water-TSB mixture, and apple juiceTSB mixture, respectively. In all media, initial bacteria concentration of $10^{2} \mathrm{CFU} / \mathrm{ml}$ and $10^{3} \mathrm{CFU} / \mathrm{ml}$ gave the significantly higher mean intensity compare to negative
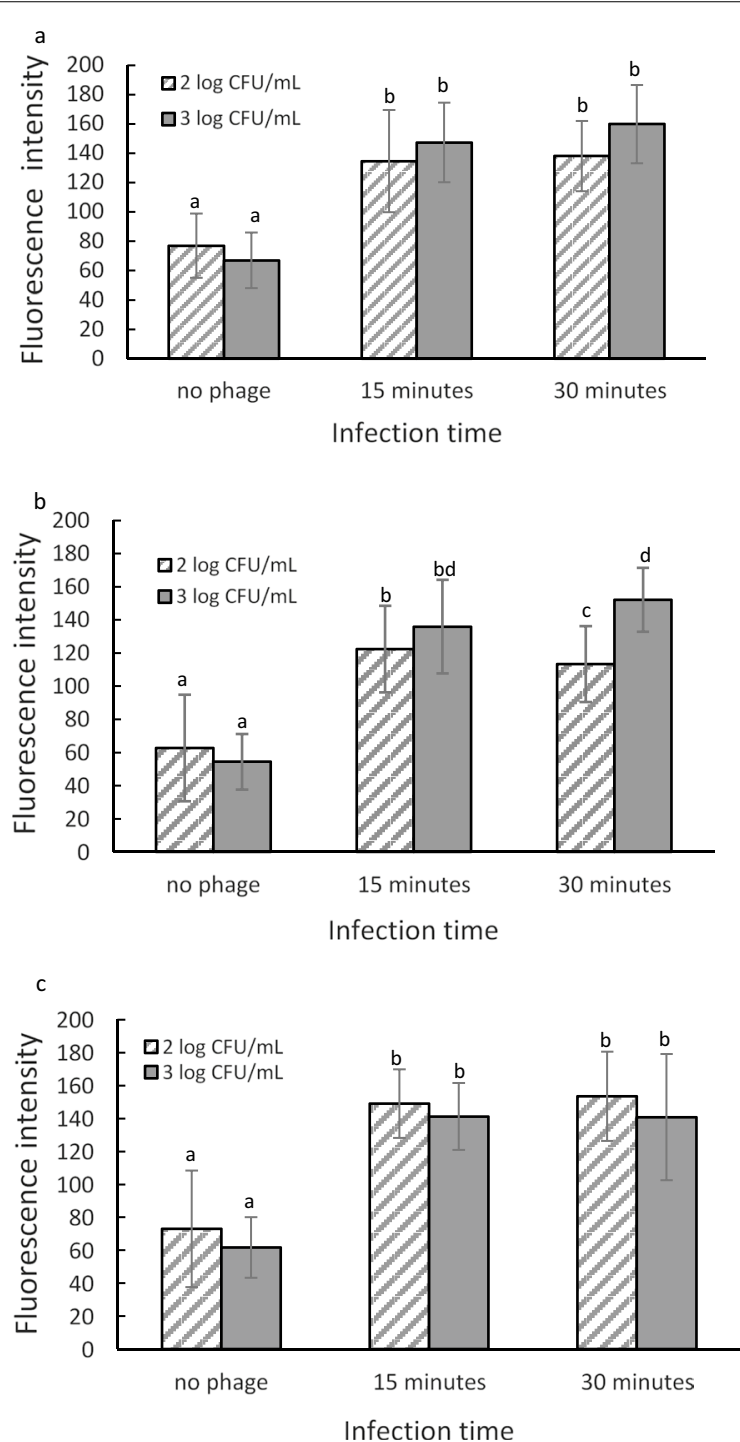

Fig. 6 Mean gray value of fluorescent images of E. coli BL21 10² CFU/ $\mathrm{ml}$ and $10^{3} \mathrm{CFU} / \mathrm{ml} 4 \mathrm{~h}$ enrichment in TSB (a), coconut water (b), and apple juice (c) after 15- and 30-min infection with bacteriophage T7-ALP. Treatments with different letters are significantly different $(P<0.05)$. Error bars indicate \pm standard deviation of means control which was bacteria with no phage infection. However, there is no significant difference $(P<0.05)$ between the mean intensity of $10^{2} \mathrm{CFU} / \mathrm{ml}$ and $10^{3} \mathrm{CFU} /$ $\mathrm{ml}$. After $30 \mathrm{~min}$ of infection in coconut water, the result indicates a decrease in the mean fluorescence intensity. This is probably due to the fact that, in coconut water, after 30 min of infection most of bacterial cells were lysed causing the release of alkaline phosphatase thus the signal was no longer localized in bacterial cells. Therefore, it is critical that the bacteria-phage mixture was filtered before lysis of bacterial cells in order to maintain the high intensity of the fluorescent signal.

\section{Detection of $E$. coli based on alkaline phosphatase activity using a soluble FDP fluorescent substrate}

Signal-to-noise ratio of the fluorescent signal when infection took place in TSB, coconut water-TSB mixture, and apple juice-TSB mixture are shown in Fig. $7 \mathrm{a}-\mathrm{c}$, respectively. In TSB, the detection limit of $E$. coli was $10^{4} \mathrm{CFU} /$ $\mathrm{ml}$ after $4 \mathrm{~h}$ of reaction with FDP substrate. For detection in beverage sample, initial cell concentration of $10^{4} \mathrm{CFU} /$ $\mathrm{ml}$ in coconut water-TSB mixture can be detected after $8 \mathrm{~h}$ of reaction, and after $12 \mathrm{~h}$ in apple juice-TSB mixture while there was no significant difference between negative control of no bacteria and E. coli $10^{3}$ and $10^{2} \mathrm{CFU} /$ $\mathrm{ml}$. To detect $10^{4} \mathrm{CFU} / \mathrm{ml}$, it requires the reaction time of $4 \mathrm{~h}, 8 \mathrm{~h}$, and $12 \mathrm{~h}$ in TSB, coconut water, and apple juice, respectively.

\section{Discussion}

Bacteriophage has been continuously employed as the valuable tool for bacteria detection due to its specificity and rapidity of the infection cycle, robustness, and lowcost preparation (Richter et al. 2018). Bacteriophage T7 and its host, E. coli, is one on the most widely studied models for bacteria detection. The simplicity of bacteriophage $\mathrm{T} 7$ genome has enabled genetically engineering for insertion of the reporter gene. Several bacteriophagebased bacteria detection approaches have been recently implemented in order to improve bacteria detection sensitivity (Table 1). These previous studies developed the detection methods based on colorimetric, bioluminescent, and electrochemical detection of enzymatic activity using substrates that yield soluble products; therefore, their detection sensitivity relies on the cell concentration and/or immobilization of the reporter enzyme on biomaterial substrates.

This study demonstrates the novel approach of enhancing the detection sensitivity by detection of reporter enzyme using precipitated substrate followed by fluorescent imaging and image analysis. From the results we established that infection of engineered bacteriophage T7-ALP coupled with the use of ELF-97 


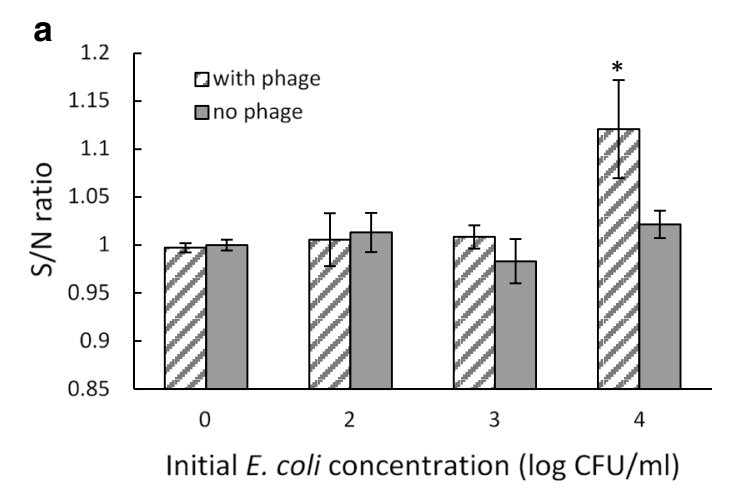

b

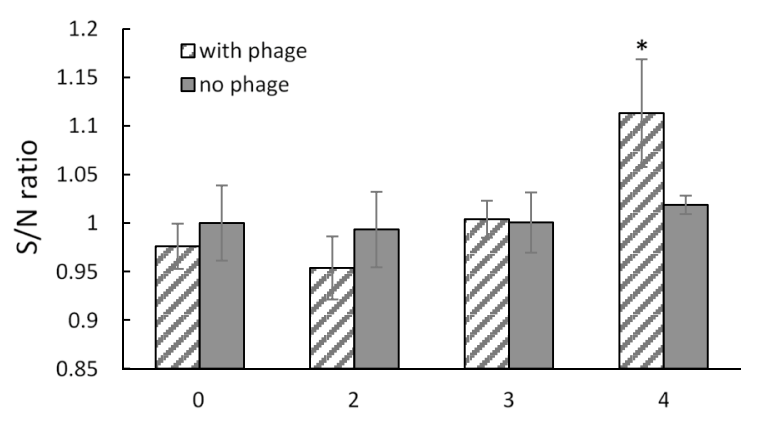

Initial E. coli concentration ( $\log \mathrm{CFU} / \mathrm{ml})$

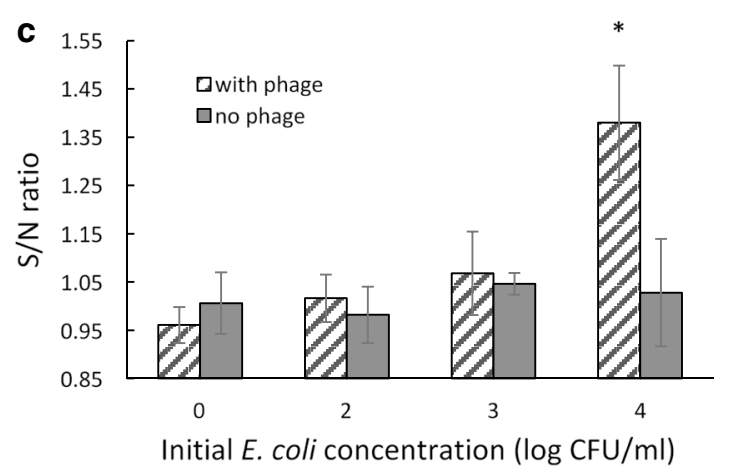

Fig. 7 Signal to noise ratio of Alkaline phosphatase over-expressed by E. coli BL21 after 4 h of enrichment in TSB (a), coconut water (b), and apple juice (c) after infection with phage T7-ALP for $30 \mathrm{~min}$. Asterisk indicates significant difference $(P<0.05)$ from negative control. Error bars indicate \pm standard deviation of means

as alkaline phosphatase substrate was a viable option that could be developed into a food safety application. Localization of the fluorescent precipitated signal inside the cell resulting in increased signal intensity allowing visualization of a single bacterial cell. Further, they are consistent with other studies. ELF-97 was used for detection of alkaline phosphatase activity as a phosphate stress marker in marine phytoplankton with fluorescent imaging and flow cytometry (González-Gil et al. 1998; Dyhrman 1999; Nedoma et al. 2003; Van Wambeke et al. 2008). ELF-97 yielded a highly sensitive detection of a single cell of phosphate-stressed marine bacteria (Duhamel et al. 2009). Huang et al. (1998) successfully used ELF-97 to detect alkaline phosphatase expression of bacteria colonies and biofilm in phosphate starvation condition (Huang et al. 1998).

Developing a robust pathogen detection system demands that the method is ultimately specific without unexpected false positive results. As bacteriophage is highly specific to bacterial host strain, other bacterial strain will not be infected by bacteriophage T7-ALP and will not overexpress alkaline phosphatase thus no fluorescent signal detected. Two strains of foodborne bacteria, L. innocua and P. fluorescens, were tested to evaluated the detection specificity. L. innocua is a nonpathogenic surrogate of Listeria monocytogenes which is a Gram-positive foodborne pathogenic bacterium commonly found in food and agricultural product (Friedly et al. 2008). While P. fluorescens is representing Gramnegative bacteria with rod shape that are commonly found in food system to cause problems with spoilage (Rajmohan et al. 2002). The results indicated no significant green fluorescent signal was detected which reinforced the potential to distinguish target bacteria from other foodborne bacterial strain. Although it might not be strictly defined as a false positive, it remains possible that the resulting alkaline phosphatase activity observed by $E$. coli following phage T7-ALP infection is due to a stress condition resulting in induction of the endogenous E. coli phoA. To test this possibility $10^{3}$ $\mathrm{CFU} / \mathrm{ml}$ of $E$. coli was infected by wildtype T7 phage. This alternative possibility of $p h o A$ expression was not supported by the experimental results, which showed no significant green fluorescent signal.

Detection of $E$. coli in the complex beverage matrices is the essential step to evaluate the effect of food component on bacteriophage infection and expression of $p h o A$ gene. When the 30-min infection took place in coconut water (Fig. 4f), green fluorescence particles were not in the cell shape yet appeared in small punctate particles. We interpret that these results show that some of the integrity of some infected cells were compromised which caused the release of alkaline phosphatase. Assuming loss of cell integrity is due to phage-mediated cell lysis following replication, then indicating that phage T7-ALP conditions provided by cultivation in coconut water-TSB may shorten the phage replicative cycle.

Escherichia coli cells, after $4 \mathrm{~h}$ of enrichment in apple juice, displayed filamentous morphology (Fig. 5) which may be due to the SOS response noted previously by other investigators (Justice et al. 2006). Apple juice contains high content of phenolic compounds which show 


\begin{tabular}{|c|c|c|c|c|c|}
\hline Method description & $\begin{array}{l}\text { Detection } \\
\text { limit }\end{array}$ & $\begin{array}{l}\text { Assay } \\
\text { time }\end{array}$ & Matrices & Potential limitations & References \\
\hline $\begin{array}{l}\text { Detection of T7-induced alkaline phos- } \\
\text { phatase activity using chemilumis- } \\
\text { cent methods }\end{array}$ & $10^{3} \mathrm{CFU} / \mathrm{ml}$ & $6 \mathrm{~h}$ & Luria Broth & $\begin{array}{l}\text { Detection of enzymatic activity can be } \\
\text { affected by background noise }\end{array}$ & $\begin{array}{l}\text { Alcaine et al. } \\
\text { (2015) }\end{array}$ \\
\hline $\begin{array}{l}\text { Detection of phage T7 amplification } \\
\text { using lateral flow assays with phage- } \\
\text { based enzymatic reporter }\end{array}$ & $10^{2} \mathrm{CFU} / 100 \mathrm{ml}$ & $9 \mathrm{~h}$ & River water & $\begin{array}{l}\text { Reduced detection efficacy in } \\
\text { complex matrices may occur due to } \\
\text { non-specific binding to antibody }\end{array}$ & $\begin{array}{l}\text { Alcaine et al } \\
\text { (2016) }\end{array}$ \\
\hline $\begin{array}{l}\text { Detection of T7-induced } \\
\beta \text {-galactosidase using colorimetric } \\
\text { substrate }\end{array}$ & $10^{2} \mathrm{CFU} / \mathrm{ml}$ & $7 \mathrm{~h}$ & $\begin{array}{l}\text { Drinking water, skim } \\
\text { milk, orange juice }\end{array}$ & $\begin{array}{l}\text { Additional cost and complexity due to } \\
\text { lyophilization }\end{array}$ & $\begin{array}{l}\text { Chen et al. } \\
\text { (2017) }\end{array}$ \\
\hline $\begin{array}{l}\text { Detection of T7-induced } \\
\beta \text {-galactosidase using electrochemi- } \\
\text { cal method }\end{array}$ & $10^{2} \mathrm{CFU} / \mathrm{ml}$ & $7 \mathrm{~h}$ & $\begin{array}{l}\text { Drinking water, skim } \\
\text { milk, orange juice }\end{array}$ & Low sample volume (1 ml) & $\begin{array}{l}\text { Wang et al. } \\
\text { (2017) }\end{array}$ \\
\hline $\begin{array}{l}\text { Detection of T7-induced luciferase and } \\
\text { alkaline phosphatase by filter-based } \\
\text { colorimetric and bioluminescence } \\
\text { method }\end{array}$ & $1 \mathrm{CFU} / 100 \mathrm{ml}$ & $10 \mathrm{~h}$ & Drinking water & $\begin{array}{l}\text { Reduced detection efficacy in } \\
\text { complex matrices may occur due } \\
\text { to background color and large food } \\
\text { particles }\end{array}$ & $\begin{array}{l}\text { Hinkley et al } \\
\text { (2018b) }\end{array}$ \\
\hline $\begin{array}{l}\text { Detection of T7-induced luciferase } \\
\text { immobilized on microcrystalline } \\
\text { cellulose }\end{array}$ & $\begin{array}{l}<10 \text { CFU per } \\
100 \mathrm{ml}\end{array}$ & $3 \mathrm{~h}$ & Drinking water & $\begin{array}{l}\text { Reduced detection efficacy in } \\
\text { complex matrices may occur due to } \\
\text { non-specific binding to cellulose }\end{array}$ & $\begin{array}{l}\text { Hinkley et al } \\
\text { (2018a) }\end{array}$ \\
\hline
\end{tabular}

antibacterial activity against E. coli (Kahle et al. 2005; Alberto et al. 2006), which may account for the induction of the filamentous cell structure. However, there was no cell with visible green fluorescent signal from precipitated ELF-97 fluorescent product showing that these apparently stressed conditions have impact on the expression of endogenous E. coli pho $A$ and, therefore, no significant green fluorescent signal detected. After bacteriophage T7-ALP infection (Fig. 5b, c, e, f), the signal was confined to distinctive segments of the filamentous cellular arrangement, revealing that phage T7-ALP replicated at this timepoint within a subset of $E$. coli cells forming the filament.

Image analysis results indicated that green fluorescence can represent the activity of phage-induced alkaline phosphatase since the signal intensity of phageinfected bacteria is significantly different from the autofluorescent of uninfected bacteria. Infection time has no influence on alkaline phosphatase activity when the media were TSB and apple juice as there is no changes in the mean fluorescence intensity. However, there was a decrease in fluorescence intensity after $30 \mathrm{~min}$ of infection in coconut water which may due to the release of alkaline phosphatase after cell lysis. This finding indicated that the natural properties and compositions of food matrices may influence the infection rate of bacteriophage which results in different optimal infection time for different food samples.

For detection of alkaline phosphatase activity using soluble substrate, FDA, the length of reaction time depends on the concentration of enzyme in the solution. Since the infection time is $30 \mathrm{~min}$, the cells were not completely lysed; therefore, phage-mediated alkaline phosphatase was not released to the solution. Unlike the signal of precipitated fluorescent substrate, the signal from soluble fluorescent substrate is dissolved in the solution resulting in lower detection sensitivity. The results also indicate the difference in reaction time required to detect $10^{4}$ $\mathrm{CFU} / \mathrm{ml}$ in difference infection media. More complexion of media resulted in more time required for $E$. coli detection using this approach as the composition of coconut water and apple juice may interfere with the reaction of alkaline phosphatase.

Overall, the results of this study indicated that the detection of alkaline phosphatase activity induced by engineered bacteriophage infection using substrate that yields precipitated fluorescence product coupled with fluorescence imaging and quantitative image analysis is a promising approach for rapid and highly specific bacterial detection. This proof-of-concept system can be applied in the real complex beverage matrices.

\footnotetext{
Authors' contributions

NN proposed concept of the study. NW and XY conducted the experiments. $\mathrm{NN}$ and GY assisted in the experimental design. NW performed data analysis and wrote the manuscript. $X Y, G Y$, and NN edited and revised the manuscript. All authors read and approved the final manuscript.
}

\section{Author details}

${ }^{1}$ Department of Food Science and Technology, University of California, Davis, CA, USA. ${ }^{2}$ Department of Biological and Agricultural Engineering, University of California, Davis, CA, USA. 


\section{Acknowledgements}

We want to thank Dr. Sam Nugen from Cornell University to provide the engineered T7 phage.

\section{Competing interests}

The authors declare that they have no competing interests.

\section{Availability of data and materials}

All necessary data supporting our conclusions are included in the article.

\section{Consent for publication}

Not applicable.

\section{Ethics approval and consent to participate}

The research does not contain any human or animal studies performed by any of the authors.

\section{Funding}

This study was supported by USDA National Institute of Food and Agriculture (USDA-NIFA) Grant No. 2015-68003-23411.

\section{Publisher's Note}

Springer Nature remains neutral with regard to jurisdictional claims in published maps and institutional affiliations.

\section{Received: 31 March 2019 Accepted: 9 April 2019}

Published online: 19 April 2019

\section{References}

Alberto MR, Canavosio MAR, Manca de Nadra MC (2006) Antimicrobial effect of polyphenols from apple skins on human bacterial pathogens. Electron J Biotechnol 9:205-209. https://doi.org/10.2225/vol9-issue

Alcaine SD, Pacitto D, Sela DA, Nugen SR (2015) Phage \& phosphatase: a novel phage-based probe for rapid, multi-platform detection of bacteria. Analyst 140:7629-7636. https://doi.org/10.1039/c5an01181g

Alcaine SD, Law K, Ho S, Kinchla AJ, Sela DA, Nugen SR (2016) Bioengineering bacteriophages to enhance the sensitivity of phage ampli fi cation-based paper fluidic detection of bacteria. Biosens Bioelectr 82:14-19. https:// doi.org/10.1016/j.bios.2016.03.047

Anany H, Chou Y, Cucic S, Derda R, Evoy S, Griffiths MW (2017) From bits and pieces to whole phage to nanomachines: pathogen detection using bacteriophages. Annu Rev Food Sci Technol 8:305-329. https://doi. org/10.1146/annurev-food-041715-033235

Chang TC, Ding HC, Chen S (2002) A conductance method for the identification of Escherichia coli 0157:H7 using bacteriophage AR1. J Food Prot 65:12-17

Chapela M-J, Garrido-Maestu A, Cabado AG (2015) Detection of foodborne pathogens by qPCR: a practical approach for food industry applications. Cogent Food Agric 1:1-19. https://doi.org/10.1080/23311932.2015.10137 71

Chen J, Alcaine SD, Jiang Z, Rotello VM, Nugen SR (2015) Detection of Escherichia coli in drinking water using $T 7$ bacteriophage-conjugated magnetic probe. Anal Chem 87:8977-8984. https://doi.org/10.1021/acs.analc hem.5b02175

Chen J, Picard RA, Wang D, Nugen SR (2017) Lyophilized engineered phages for Escherichia coli detection in food matrices. ACS Sens 2:1573-1577. https://doi.org/10.1021/acssensors.7b00561

Duhamel S, Gregori G, Van Wambeke F, Nedoma J (2009) Detection of extracellular phosphatase activity at the single-cell level by enzyme-labeled fluorescence and flow cytometry: the importance of time kinetics in ELFA labeling. Cytom Part A 75:163-168. https://doi.org/10.1002/cyto.a.20686

Dyhrman ST (1999) Phosphate stress in cultures and field populations of the Dino agellate. Society 65:3205-3212

Friedly EC, Crandall PG, Ricke S, O'Bryan CA, Martin EM, Boyd LM (2008) Identification of Listeria innocua surrogates for Listeria monocytogenes in hamburger patties. J Food Sci 73:174-178. https://doi.org/10.111 1/j.1750-3841.2008.00719.x
González-Gil S, Keafer BA, Jovine RVM, Aguilera A, Lu S, Anderson DM (1998) Detection and quantification of alkaline phosphatase in single cells of phosphorus-starved marine phytoplankton. Mar Ecol Prog Ser 164:21-35. https://doi.org/10.3354/meps164021

Goodridge L, Griffiths M (2002) Reporter bacteriophage assays as a means to detect foodborne pathogenic bacteria. Food Res Int 35:863-870. https:// doi.org/10.1016/S0963-9969(02)00094-7

Griffiths MW (1996) The role of ATP bioluminescence in the food industry: new light on old problems. Food Technol 50:62-72

Hagens S, Loessner MJ (2007) Application of bacteriophages for detection and control of foodborne pathogens. Appl Microbiol Biotechnol 76:513-519. https://doi.org/10.1007/s00253-007-1031-8

Hennes KP, Suttle CA, Chan AM (1995) Fluorescently labeled virus probes show that natural virus populations can control the structure of marine microbial communities. Appl Environ Microbiol 61:3623-3627

Hinkley TC, Garing S, Singh S, Ny ALM, Nichols KP, Peters JE, Talbert JN, Nugen SR (2018a) Reporter bacteriophage T7 NLC utilizes a novel NanoLuc:CBM fusion for the ultrasensitive detection of Escherichia coli in water. Analyst. https://doi.org/10.1039/c8an00781k

Hinkley TC, Singh S, Garing S, Ny AM, Nichols KP, Peters JE, Talbert JN, Nugen SR (2018b) A phage-based assay for the rapid, quantitative, and single CFU visualization of E. coli (ECOR \# 13) in drinking water. Sci Rep. https:// doi.org/10.1038/s41598-018-33097-4

Hoffmann S, Maculloch B, Batz M (2015) Economic burden of major foodborne illnesses acquired in the United States. Econ Res Serv. https://doi. org/10.1001/jamadermatol.2014.3593

Huang Z, You W, Haugland RP, Paragas VB, Olson NA (1993) A novel fluorogenic sunstrate for detecting alkaline phosphatase activity in situ. J Histochem Cytochem 41:313-317

Huang C, Xu KD, Mcfeters GA, Stewart S, Feters GA (1998) Spatial patterns of alkaline phosphatase expression within bacterial colonies and biofilms in response to phosphate starvation. Appl Environ Microbiol 64:1526-1531

Ivnitski D, Abdel-Hamid I, Atanasov P, Wilkins E (1999) Biosensors for detection of pathogenic bacteria. Biosens Bioelectron 14:599-624. https://doi. org/10.1016/S0956-5663(99)00039-1

Justice SS, Hunstad DA, Seed PC, Hultgren SJ (2006) Filamentation by Escherichia coli subverts innate defenses during urinary tract infection. Proc Natl Acad Sci 103:19884-19889. https://doi.org/10.1073/pnas.0606329104

Kahle K, Kraus M, Richling E (2005) Polyphenol profiles of apple juices. Mol Nutr Food Res 49:797-806. https://doi.org/10.1002/mnfr.200500064

Kim J, Kim M, Kim S, Ryu S (2017) Sensitive detection of viable Escherichia coli 0157:H7 from foods using a luciferase-reporter phage phiV10lux. Int J Food Microbiol 254:11-17. https://doi.org/10.1016/j.ijfoodmicr 0.2017 .05 .002

Koyuncu S, Haggblom P (2009) A comparative study of cultural methods for the detection of Salmonella in feed and feed ingredients. BMC Vet Res 5:6. https://doi.org/10.1186/1746-6148-5-6

Kralik P, Ricchi M (2017) A basic guide to real time PCR in microbial diagnostics: definitions, parameters, and everything. Front Microbiol 8:1-9. https://doi. org/10.3389/fmicb.2017.00108

Kutin RK, Alvarez A, Jenkins DM (2009) Detection of Ralstonia solanacearum in natural substrates using phage amplification integrated with real-time PCR assay. J Microbiol Methods 76:241-246. https://doi.org/10.1016/j. mimet.2008.11.008

Loessner MJ, Rudolf M, Scherer S, Loessner MJ, Rudolf M, Scherer S (1997) Evaluation of luciferase reporter bacteriophage A511: luxAB for detection of Listeria monocytogenes in contaminated foods. Appl Environ Microbiol 63:2961-2965

Marder EP, Cieslak PR, Cronquist AB, Dunn J, Lathrop S, Rabatsky-ehr T (2017) Incidence and trends of infections with pathogens transmitted commonly through food and the effect of increasing use of cultureindependent diagnostic tests on surveillance. Foodborne Dis Active Surv. 66:398-402

McComb RB, Bowers GN Jr, Posen S (1979) Alkaline phosphatase. Plenum Press, New York

Nedoma J, Štrojsová A, Vrba J, Komárková J, Šimek K (2003) Extracellular phosphatase activity of natural plankton studied with ELF97 phosphate: fluorescence quantification and labelling kinetics. Environ Microbiol 5:462-472. https://doi.org/10.1046/j.1462-2920.2003.00431.x

Oda M, Morita M, Unno H, Tanji Y (2004) Rapid detection of Escherichia coli O157: H7 by using green fluorescent protein-labeled PP01 
bacteriophage. Appl Environ Microbiol 70:527-534. https://doi. org/10.1128/AEM.70.1.527

Paragas VB, Zhang Y-Z, Haugland RP, Singer VL (1997) The ELF-97 Alkaline phosphatase substrate provides a bright, photostable, fluorescent signal amplification method for FISH. J Histochem Cytochem 45:345-357. https ://doi.org/10.1177/002215549704500302

Paragas VB, Kramer JA, Fox C, Haugland RP, Singer VL (2002) The ELF ${ }^{\circledR}-97$ phosphatase substrate provides a sensitive, photostable method for labelling cytological targets. J Microsc 206:106-119. https://doi.org/10.10 46/j.1365-2818.2002.01017.x

Peacock MB, Kudela RM (2012) A method for determining alkaline phosphatase activity in marine phytoplankton using spectrofluorometry J Microbiol Methods 89:209-212. https://doi.org/10.1016/j.mimet .2012.03.007

Piuri M, Jacobs WR, Hatfull GF (2009) Fluoromycobacteriophages for rapid, specific, and sensitive antibiotic susceptibility testing of Mycobacterium tuberculosis. PLoS ONE 4:e4870. https://doi.org/10.1371/journ al.pone. 0004870

Prades A, Dornier M, Diop N, Pain J-P (2012) Coconut water uses, composition and properties: a review. Fruits 67:87-107. https://doi.org/10.1051/fruit s/2012002

Rajmohan S, Dodd CER, Waites WM (2002) Enzymes from isolates of Pseudomonas fluorescens involved in food spoilage. J Appl Microbiol 93:205-213. https://doi.org/10.1046/j.1365-2672.2002.01674.x

Reiman RW, Atchley DH, Voorhees KJ (2007) Indirect detection of Bacillus anthracis using real-time PCR to detect amplified gamma phage DNA. J Microbiol Methods 68:651-653. https://doi.org/10.1016/j.mimet .2006 .11 .004

Richter Ł, Janczuk-Richter M, Niedziółka-Jönsson J, Paczesny J, Hołyst R (2018) Recent advances in bacteriophage-based methods for bacteria detection. Drug Discov Today 23:448-455. https://doi.org/10.1016/j.drudi S.2017.11.007

Rossen L, Nørskov P, Holmstrøm K, Rasmussen OF (1992) Inhibition of PCR by components of food samples, microbial diagnostic assays and DNA-extraction solutions. Int J Food Microbiol 17:37-45. https://doi org/10.1016/0168-1605(92)90017-W
Scallan E, Hoekstra RM, Angulo FJ, Tauxe RV, Widdowson MA, Roy SL, Jones JL, Griffin PM (2011) Foodborne illness acquired in the United States-major pathogens. Emerg Infect Dis 17:7-15. https://doi.org/10.3201/eid17 01.P11101

Schrader C, Schielke A, Ellerbroek L, Johne R (2012) PCR inhibitors-occurrence, properties and removal. J Appl Microbiol 113:1014-1026. https:// doi.org/10.1111/j.1365-2672.2012.05384.x

Shen Z, Hou N, Jin M, Qiu Z, Wang J, Zhang B, Wang X, Wang J, Zhou D, Li J (2014) A novel enzyme-linked immunosorbent assay for detection of Escherichia coli O157:H7 using immunomagnetic and beacon gold nanoparticles. Gut Pathog 6:1-8. https://doi.org/10.1186/1757-4749-6-14

Singh A, Poshtiban S, Evoy S (2013) Recent advances in bacteriophage based biosensors for food-borne pathogen detection. Sensors (Switzerland) 13:1763-1786. https://doi.org/10.3390/s130201763

Smartt AE, XU T, Jegier P, Carswell JJ, Blount SA, Sayler GS, Ripp S (2012) Pathogen detection using engineered bacteriophages. Anal Bioanal Chem 402:3127-3146. https://doi.org/10.1007/s00216-011-5555-5

Telford WG, Cox WG, Stiner D, Singer VL, Doty SB (1999) Detection of endogenous alkaline phosphatase activity in intact cells by flow cytometry using the fluorogenic ELF-97 phosphatase substrate. Cytometry 37:314-319

Van Wambeke F, Nedoma J, Duhamel S, Lebaron P (2008) Alkaline phosphatase activity of marine bacteria studied with ELF 97 substrate: success and limits in the P-limited Mediterranean Sea. Aquat Microb Ecol 52:245-251. https://doi.org/10.3354/ame01238

Wang D, Chen J, Nugen SR (2017) Electrochemical detection of Escherichia coli from aqueous samples using engineered phages. Anal Chem 89(3):16501657. https://doi.org/10.1021/acs.analchem.6b03752

WHO (2015) WHO estimates of the global burden of foodborne diseases. Who. https://doi.org/10.1016/j.fm.2014.07.009

Yim PB, Clarke ML, McKinstry M, De Paoli Lacerda SH, Pease LF, Dobrovolskaia MA, Kang HG, Read TD, Sozhamannan S, Hwang J (2009) Quantitative characterization of quantum dot-labeled lambda phage for Escherichia coli detection. Biotechnol Bioeng 104:1059-1067. https://doi. org/10.1002/bit.22488

\section{Submit your manuscript to a SpringerOpen ${ }^{\circ}$ journal and benefit from:}

- Convenient online submission

- Rigorous peer review

- Open access: articles freely available online

- High visibility within the field

- Retaining the copyright to your article

Submit your next manuscript at $\boldsymbol{\nabla}$ springeropen.com 